\title{
Mordida aberta anterior: uma fórmula para o diagnóstico diferencial $* * * *$
}

\author{
Anterior open bite: a formula for the differential diagnosis
}

Heloísa Canesin Alimere* (heloalimere@bol.com.br)

Adílson Thomazinho**

Cláudia Maria de Felício***

*Fonoaudióloga. Especialização em Motricidade Oral pela Universidade de Ribeirão Preto (Unaerp)

***irurgião-Dentista. Doutor em Ortodontia pela Universidade Estadual de Campinas.

Professor Doutor do Departamento de Clínica Infantil e Odontologia

Preventiva e Social da Faculdade de Odontologia de Ribeirão Preto Universidade de São Paulo (USP).

***Fonoaudióloga. Doutora em Ciências (Psicobiologia) pela Faculdade de Filosofia Ciências e Letras de Ribeirão Preto da USP Professora Doutora do Departamento de Oftalmologia, Otorrinolaringologia e Cirurgia de Cabeça e Pescoço da Faculdade de Medicina de Ribeirão Preto da USP.

*****Trabalho Realizado na Faculdade de Odontologia de Ribeirão Preto da USP - Departamento de Clínica Infantil e Odontologia Preventiva e Social e no Curso de Especialização em Motricidade Oral da Unaerp.

Artigo de Pesquisa

Artigo Submetido a Avaliação por Pares

Conflito de Interesse: não

Recebido em 16.08.2004

Revisado em 3.11.2005; 21.04.2005; 17.06.2005; 11.11.2005.

Aceito para Publicação em 11.11.2005.

\section{Abstract}

Background: the differentiation between dental and skeletal anterior open bite, both with distinct etiologies and characteristics, is necessary to establish adequate orthodontic and speech-language treatment procedures. Aim: to establish a formula for the differential diagnosis of dental anterior open bite and skeletal anterior open bite based on a cephalometric analysis of the angles that measure the mandibular plane inclination (NS.GoGn), the vertical and anteroposterior mandibular growth (NSGn), and the Facial Axis angle. Method: 78 lateral radiographies, of individuals with ages varying from 6 to 13 years, were analyzed and divided into two groups: dental anterior open bite and skeletal anterior open bite. Results: there was a significant difference between the groups regarding the measurements of the angles: for the group with skeletal anterior open bite the NS.GoGn and the NSGn angles were bigger and the Facial Axis angle was smaller when compared to the group with dental anterior open bite. The adjustment to the linear function resulted in a formula that determines the type of anterior open bite with only $3.5 \%$ of error. Conclusions: it was possible to establish a high precision formula for the differential diagnosis between dental and skeletal open bite, based on the angle measurements of NS.GoGn NSGn and Facial Axes. The presented formula for the differential diagnosis has research and clinical applicability.

Key Words: Open Bite; Cephalometry; Speech; Language and Hearing Science.

\section{Resumo}

Tema: diferenciar a mordida aberta anterior dental da mordida aberta anterior esquelética é necessário para que se estabeleça as metas e as condutas de tratamento ortodôntico e fonoaudiológico, tendo em vista que estas má oclusões têm etiologia e características morfofisiológicas distintas. Objetivo: estabelecer uma fórmula para o diagnóstico diferencial entre mordida aberta anterior dental e mordida aberta anterior esquelética, baseado na análise cefalométrica composta pelos ângulos que medem a inclinação do plano mandibular (NS.GoGn), a direção do crescimento mandibular no sentido vertical e ântero-posterior (NSGn), e a direção de crescimento mandibular e a posição vertical do mento (Eixo Facial). Método: 78 radiografias em norma lateral, de sujeitos com idade variando de 6 a 13 anos, foram analisadas e divididas em dois grupos - mordida aberta anterior dental e mordida aberta anterior esquelética. Resultado: Houve diferença significante entre os grupos quanto aos valores das medidas angulares, sendo que no grupo mordida aberta anterior esquelética as medidas dos ângulos NS.GoGn e NSGn foram maiores e do ângulo Eixo Facial menores em comparação ao grupo mordida aberta anterior dental. $\mathrm{O}$ ajuste dos dados à função linear resultou numa fórmula que permite definir o tipo de mordida aberta anterior a partir das referidas medidas angulares, com apenas 3,5\% de margem de erro. Conclusão: foi possível estabelecer uma fórmula para o diagnóstico diferencial da mordida aberta anterior dental e mordida aberta anterior esquelética, o qual pode ser realizado com alto grau de confiança, a partir das medidas angulares NS.GoGn, NSGn e Eixo Facial. A fórmula estabelecida para o diagnóstico diferencial possui aplicabilidade em pesquisas e na clínica.

Palavras-Chave: Mordida Aberta; Cefalometria; Fonoaudiologia. 


\section{Introduction}

The open bite may be defined as a disorder in the normal vertical contact between antagonist teeth and may be manifested in a limited region or even in the whole dental arch, although more rarely. The open bites may be divided into two categories: dental and skeletal (Burford \& Noar, 2003). In the dental open bite, or dentoalveolar, the disorder occurs during the teeth eruption and the alveolar growth. In this type of malocclusion the skeletal components are relatively normal. In the skeletal open bite, besides the dentoalveolar disorders, there is a lack of proportion between the several bones of the craniofacial complex (Proffit, 2000).

Angle, in 1907, already insisted that the professional should be aware of the inter-relation between the teeth and the maxillas with the face, therefore inferring the necessity of a deep knowledge of its parts growth. Ferrugini et al. (2002) stresses that it is extremely important for the speech pathologist to understand the concepts related to the craniofacial growth and development.

The orofacial myofunctional disorders are frequently present in cases of anterior open bite. These disorders may be associated to harmful oral habits including sucking (Santos et al., 2000; Cirelli et al., 2001; Felício et al., 2003). It is considered that harmful habits followed by functional disorders may originate the alveolar open bite. In cases of skeletal open bite, the habits would act as aggravating factors and the orofacial myofunctional disorders would be adaptations to the altered morphologic condition. Several authors have studied and discussed the myofunctional disorders in cases of open bites, focusing specially on swallowing (Cayley et al, 2000; Fayyat, 2000; Lopes, 2000; Pacheco et al., 2000; Kawamura et al., 2003; Yamaguchi \& Sueishi, 2003; Fujiki et al., 2004).

The orthodontic treatment planning differs according to the open bite etiology and diagnosis (Henriques et al., 2000). The same way, the speech pathologist needs to establish different goals and therapeutic conducts in cases of dentoalveolar or skeletal open bites (Felício, 2001).

Therefore, the differential diagnosis between dental and skeletal anterior open bite is very important and the radiographic cephalometry is an excellent diagnostic tool of these abnormalities that helps to determine the most adequate procedures for the treatment. Steiner (1953) affirmed that the cephalometric tracing, even if not mathematically and geometrically exact, provides a good interpretation of the results, a more scientific guiding for the diagnosis and for the orthodontic treatment planning.

The aim of this research was to investigate the differential diagnosis between dental and skeletal anterior open bite based on the chephalometric analysis composed of three angular measures, that is, the angles that measure the mandibular plane (Ns.GoGn), the vertical and anteroposterior mandibular growth (NSGn) and the mandibular growth and the vertical position of the menton (Facial Axis), and to establish a mathematical formula for clinical and research application.

\section{Method}

The Project of this study was approved by the Research Ethics Committee of the University of Ribeirão Preto, under № 2003.1.140.583.

Eighty (80) cephalometric radiographs and 80 pairs of study models belonging to Brazilian children, leucoderms, from both genders, ranging in age from 6:3 to 12 years (mean age 8:4), living in Ribeirão Preto were selected from the files of the Orthodonty Discipline of the Odontology Faculty of Rbeirão Preto of Uiniversity of São Paulo. All patients presented anterior open bite and had been radiographed in lateral norm, according to the Broadbent's technique, with the habitual occlusion of the teeth. For that, the following equipments were used: X-Mind Tome (Soredex) X ray devices, of $66 \mathrm{Kwp}, 10 \mathrm{~mA}$ and exposing time of 1,6 seconds; cephalostat type Broadbent-Bolton; film-drawer size $18 \mathrm{~cm}$ x $24 \mathrm{~cm}$ with intensifying screen; Kodak radiographic films size $18 \mathrm{~cm}$ x $24 \mathrm{~cm}$ and plumbiferous apron for the patient's protection.

The cephalometric traces were obtained from the files' teleradiographs, and then the cephalometric measures were obtained from the odontologist. The equipment used in these procedures were: Newdent fluorescent light; paper ultraphan $\mathrm{n}^{\circ} 7$, size $18 \mathrm{~cm}$ x $24 \mathrm{~cm} ; 3 \mathrm{M}$ adhesive tape; black card board; Newdent magnifying glass; mechanical pencil with $n^{\circ} 3$ graffiti; Concise protractor with approximation of $1 / 2$ degree; Desetec millimeter ruler with approximation of $1 / 2 \mathrm{~mm}$, Dentaurum compass $n^{\circ} 030-395$ to measure the open bite, individually, in each pair of model.

For each case, the cephalogram composed of three angular cephalometric measures was traced from the radiographs. No files' tracing or measure performed previously was used. 
In order to standardize the cephalometric measures of the bilateral anatomic structures that presented two radiographic images, it was used the image closer to the film (in this study, the left side one), that represents more accurately the real size of the radiographic structures.

For the obtaining of cephalometric measures, some points, lines and cephalometric planes were used, as defined by Krogman \& Sassouni (1957) as:

- point S (sella turcica): located in the centre of the sella turcica of the sphenoid and is determined by inspection;

- point $\mathrm{N}$ (nasion): located in the most anterior point of the nasofrontal suture, seen in lateral norm;

- point Ba (basion): located most posterior and inferior point of the anterior border of the foramen magnum;

- point Pt (pterygoid): is the most superior and posterior point of the upper border of the left pterygo maxillary fissure;

- point Gn (gnathion): located in the external border of the menton symphysis, determined by the bisector of the angle formed by the facial line and the mandibular plane;

- point Go (gonial): located in the external border of the gonial angle, determined by the bisector of the angle formed by the mandibular plane and the ramus of the mandible;

- point Pog (pogonion): corresponds to the most anterior point of the bony menton and is determined by inspection;

. line SN (sella-nasion): determined by the union of points $\mathrm{S}$ and $\mathrm{N}$;

. line NBa (nasion-basion): formed by the line that unites points $\mathrm{N}$ and $\mathrm{Ba}$;

. line $\mathrm{S}-\mathrm{Gn}$ (sella-gnathion): is the line that passes by points $\mathrm{S}$ and $\mathrm{Gn}$;

. line $\mathrm{Pt}-\mathrm{Gn}$ (pterygoid-gnathion): is the line that unites points $\mathrm{Pt}$ and $\mathrm{Gn}$;

. line N - Pog (nasion-pogonion), also known as facial line, is determined by the union of points $\mathrm{N}$ and Pog;

- Steiner mandibular plane: formed by the union of points Go and Gn; .ramus of the mandible plane: is a tangent line that to the left posterior edge of the mandible.

Figure 1 shows the cephalometric points, lines and planes used.

FIGURE 1. Cephalometric tracing of the anatomical structures, with the cephalometric points, lines and planes.

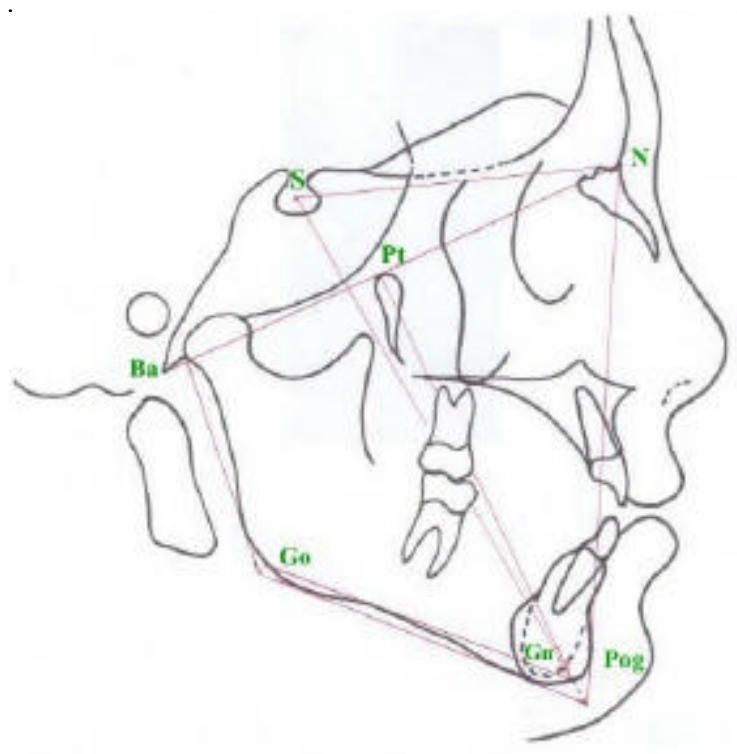


From the cephalograms traced individually for each case, the facial skeletal pattern was analyzed in the vertical plane through the following cephalometric measures:

. Steiner's Angle NS.GoGn, formed by the intersection of line SN with the Steiner mandibular plane (GoGn). Measures the inclination of the mandibular plane regarding the anterior base of the cranium. Expresses the opening degree and the anterior portion vertical height of the mandible, also determining the vertical growth pattern;

. Riedel's Angle NSGn, determined by two lines: NS and SGn, that cross each other at the point S. Registers the vertical and anteroposterior mandibular growth;

- Ricketts' facial axis Angle, determined by the intersection of line NBa with line Pt-Gn.

Measures the mandibular growth direction and expresses the vertical position of the menton.

The facial skeletal pattern analysis, through the cephalometric measurements in the vertical plane allowed to divide the 80 initial radiographs in two distinct groups, both with anterior open bite.

The first one, the dentoalveolar open bite group (Group D) was composed by 40 cases whose cephalometric measures mentioned before were close to the normal values, indicating that there was no skeletal etiologic factor responsible for the anterior open bite.

The second group, also comprising 40 cases, presented a morphological pattern peculiar to those patients whose facial growth is predominantly vertical. The cephalometric measures values of NS.Go.Gn, NSGn and facial axis angle were distant from the considerably normal values, indicating a predominance of the vertical growth of the face, a clockwise rotation, and a marked inclination of the mandible plane. This group received the name of skeletal anterior open bite group (Group E).

The procedure used to measure the anterior open bite, in both groups, is the following: in the articulated study models, a compass was placed at the mid point (mesio-dental way) of the incisal edge of the central upper incisor and the compass was opened until the other end, touching the incisal edge of the central lower incisor, the same side as its antagonist. The measure registered by the compass was transported to a millimeter ruler and the anterior open bite reading was done directly over the ruler.

Groups were analyzed regarding children's age. In order to separately compare each one of the cephalometric measure, NS.GoGn, NSGn and Facial Axis, the Student-t test was used. The statistical technique of multi-variance analysis, named discrimination analysis, was used in order to examine whether those measures allow the classification of an individual as having dentoalveolar or skeletal anterior open bite, when considered together.

\section{Results}

The casuistic of this study was initially composed by 40 documentations of children with dentoalveolar anterior open bite (Group D) and 40 with skeletal anterior open bite (Group E). Two documentation, one from group $\mathrm{D}$ and another form group E were eliminated from the sample due to registration problems. Each group was then composed by 39 documentations.

Children's age at the registration time varied between $6: 3$ and 12 years. Children from group D presented mean age slightly superior to group E. Table 1 presents the descriptive measures of children's age by group. The age differences were considered insignificant for the study.

The values of the anterior open bites found varied from 3,0 to $10,0 \mathrm{~mm}$.

TABLE 1. Descriptive measures of children's age by group, in months

\begin{tabular}{|c|c|c|c|c|c|}
\hline \multirow{2}{*}{ Grupo } & \multicolumn{5}{|c|}{ Idade } \\
\hline & Mínima & Mediana & Máxima & Média & Desvio-Padrão \\
\hline dentoalveolar & 81 & 102 & 144 & 103,2 & 14,1 \\
\hline esquelética & 75 & 98 & 124 & 99,3 & 12,2 \\
\hline
\end{tabular}


The tests results showed that the angles NS.GoGn averages of Group D and of Group E, were statistically different $(t=9,77, p<0,001)$. The same was verified when comparing the angles NSGn averages $(\mathrm{t}=12,44 ; \mathrm{p}<0,001)$ and Facial axis $(\mathrm{t}=14,17 ; \mathrm{p}<0,001)$. The averages and standard deviation values for each measure in each group, as well as the Student-t test results are presented in Table 2.
The graphic comparison of each variable measures suggests that there is a marked tendency for individuals from Group $\mathrm{E}$ to present higher averages of NSGn, and lower Facial axis, than individuals from Group D, reflected on these measures averages. Graphs 1, 2 show the values of the variables NS.GoGn and Facial axis regarding children's age. It can be observed that the angles measures are not related to age.

TABLE 2. Averages and Standard Deviation of each group's cephalometric measures and t- test results for the average of each measure.

\begin{tabular}{cc|cc|c|cc} 
& \multicolumn{2}{c|}{ Grupo D } & \multicolumn{2}{c}{ Grupo E } & \multirow{2}{*}{ t } & \multicolumn{2}{c}{ p-value } \\
\cline { 2 - 5 } Medida Cefalométrica & Média & Desvio-Padrão & Média & Desvio-Padrão & & \\
NS.GoGn & 33,14 & 2,98 & 41,03 & 4,06 & 9,769 & $<0,001$ \\
NSGn & 66,56 & 2,17 & 72,60 & 2,11 & 12,440 & $<0,001$ \\
eixo facial & 89,60 & 1,95 & 83,13 & 2,08 & 14,169 & $<0,001$ \\
\hline
\end{tabular}

GRAPH 1. Angle NS.GoGn measures according to the age and the group.

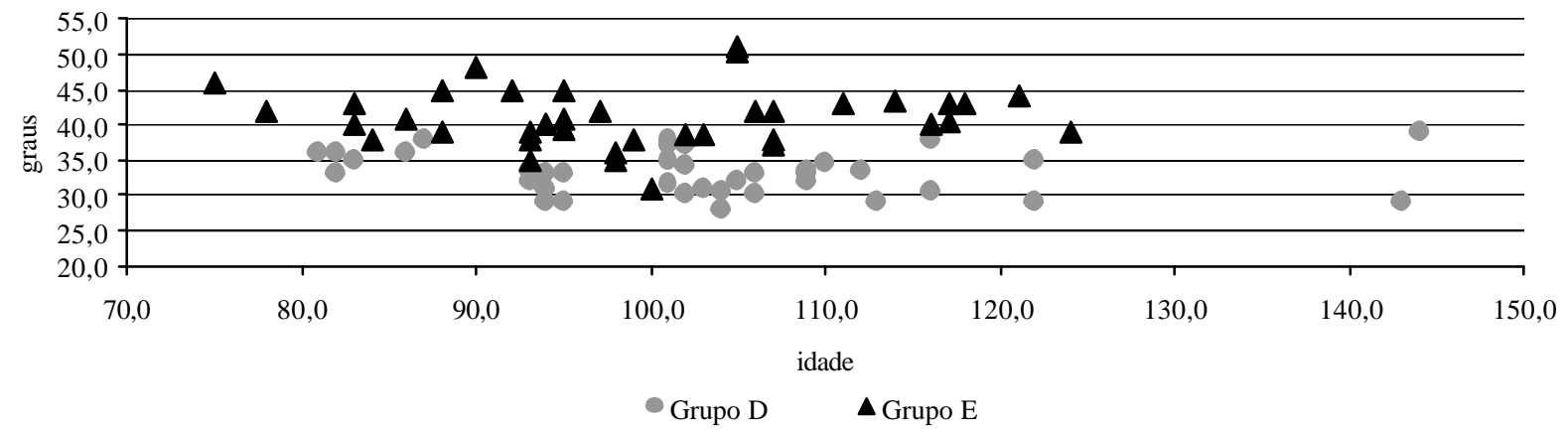

GRAPH 2. Facial axis angle measures according to the age and the group.

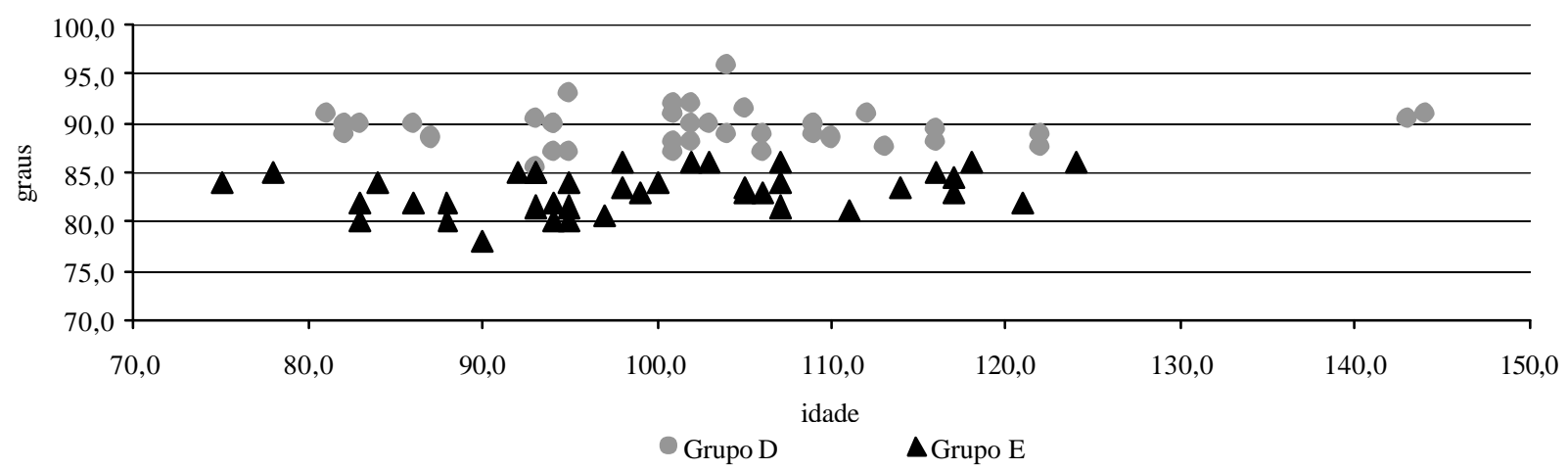


In order to examine whether these measures, considered together, allow to classify an individual as having alveolar or skeletal anterior open bite, the statistical technique of multi-variance analysis (discriminant analysis) was used. This statistical analysis also allows to establish criteria for the identification of the group to which the new individuals that will be studied belong, as well as to establish a probability of an incorrect classification. The determinant linear function adjusted for the data was defined by:

$$
y=-0,2787 \cdot x_{1}-0,5422 \cdot x_{2}+1,2029 \cdot x_{3}
$$

where $\mathrm{x}_{1}=$ measure of NS.GoGn; $\mathrm{x}_{2}=$ measure of NSGn; $x_{3}=$ measure of Facial Axis.

The mean value of $y$ for the dentoalveolar Group is $y_{d}=62,46$ and for the skeletal Group is $y_{e}$ $=49,20$. The Mahalanobis test for the difference between the averages $\mathrm{y}_{\mathrm{d}}$ and $\mathrm{y}_{\mathrm{e}}$ of the discriminant function values indicates a statistically significant difference between them $\left(\mathrm{F}_{(3,74)}=83,916 ; \mathrm{p}<0,001\right)$.

Considering the intermediary value between $y_{d}$ and $y_{e}$ as the classification criterion for the inclusion of a subject in a given group, the subject presenting y value higher than 55,83 is classified as belonging to Group D and the subject presenting y value lower ore equal to 55,83 is classified as belonging to Group E. Applying this classification criterion to the studied subjects, it was verified a total concordance with the original classification.

With this classification criterion, it is expected that only $3,5 \%$ of each group's individuals may be incorrectly classified; that is, there is a 3,5 chance in 100 that one subject belonging to one group is classified as belonging to the other.

\section{Discussion}

The aim of this research was to verify the possibility of establishing the differential diagnosis between the dentoalveolar and the skeletal anterior open bite through a classification analysis composed of three angular measures: NS.GoGn, NSGn e Facial Axis, and to establish a mathematical formula for those patients classification.

According to the statistical analysis results, there was a significant difference between Group $\mathrm{D}$ and Group E regarding the averages of the investigated measures; in Group E there was a tendency for higher measures of NS.GoGn and NSGn, and lower averages of Facial Axis. Results indicated that those variables' values were not related to the subjects' age, eliminating a possible effect of the developmental phase on the differences found in the angular measures.

Nevertheless, one must consider that, according to Proffit \& Fields (1983), not all individuals who become adults with long faces present such pattern before puberty; however, when this pattern is already manifested in childhood, the subject will rarely grow out of it.

The data analysis allowed the establishment of a discriminant function that, not only confirmed the initial classification of each group's subjects, but will also allow the future classification of patients with open bite, with clinical or research purposes and a very little margin of error.

Therefore, base don this study, one may affirm that the measures of the angles NS.GoGn, SNGn and Facial axis together are reliable for the differential diagnosis between the dentoalveolar and the skeletal anterior open bite.

Reliable methods for the diagnosis and treatment planning of malocclusions, such as cephalometry, photography use and anthropomorphic measures have been investigated for years. These methods have showed to be also important for the Speechlanguage and Hearing Science (Puliti, 2002).

The cephalometric analysis has been employed aiming at identifying the growth characteristics and alterations of people with malocclusion (Proffit \& Fields, 1983; Faria et al., 2002; Klocke et al., 2002; Beane et al., 2003), performing the differential diagnosis between the dentoalveolar and the skeletal open bite, and analyzing the treatment's results (Lopes, 2000; Cayley et al., 2000, Stuani et al., 2000; Aras, 2002; Janson et al., 2003; de Freitas et al., 2004).

Speech pathologists started to incorporate the cephalometric analysis as a diagnostic approach after the publication of Bianchini, in 1993. According to the author, cephalometry enables the evaluation of the harmony between the bone parts and the soft tissues that are extremely important for the speech-language diagnosis.

Boni (1997) used angular and linear cephalometric measures to analyze effect of the sucking habit removal on children with open bite, and Degan (2004) also used them to verify the effect of oral myofunctional therapy after the sucking habit removal.

Certainly there are oral myofunctional disorders associated to open bite cases (Cayley et al., 2000; Kawamura et al., 2003; Yamaguchi \& Sueishi, 2003; Fujiki et al., 2004), however it is necessary to establish the priorities according to the type of malocclusion. 
Felício (2001), based on the angles measures of NS.GoGn, NSGn and Facial Axis proposed differential speech-language therapeutic goals and conducts, and in cases of skeletal open bite, emphasis should be placed mainly on the mandible elevator muscle development regarding width, tonus and chewing strength. Whereas in dentoalveolar open bites, focus should be on tongue and lips functional adequacy.

Thus, it is necessary to consider objective data that allow the adequate diagnosis of the type of open bite, such as the ones analyzed in this study. It is only necessary to get the patients' documentation measures and apply the established formula to identify to which group the new individuals (who will be studied) belong, as well as to establish the probability of an incorrect classification.

Therefore, the speech pathologist may use a reliable and valid approach for the diagnosis and therapy planning of patients with anterior open bite.

\section{References}

ANGLE, E. H. Maloclusion of the teeth. 7. ed. Philadelphia: PA. S. S. White Dental Manufacturing Co., 1907.

ARAS, A. Vertical changes following orthodontic extraction treatment in skeletal open bite subjects. Eur. J. Orthod., London, v. 24, n. 4, p. 407-416, aug. 2002.

BEANE, R. A.; REIMANN, G.; PHILLIPS, C.; TULLOCH, C. A cephalometric comparison of black open-bite subjects and black normals. Angle Orthod., Appleton, v. 73, n. 3, p. 294-300, jun. 2003.

BIANCHINI, E. M. G. A Cefalometria nas alterações miofuncionais orais: diagnóstico e tratamento fonoaudiológico. Carapicuíba: Pró-Fono, 1993. 107 p.

BONI, R. C. Comportamento da mordida aberta anterior, após a remoção do hábito de sucção. 1997.98 f. Dissertação (Mestrado em Fisiologia Oral) - Faculdade de Odontologia de Piracicaba da Universidade Estadual de Campinas, Piracicaba

BURFORD, D.; NOAR, J. H. The causes, diagnosis and treatment of anterior open bite. Dent. Update, London, v. 30, n. 5, p. 235-241, jun. 2003.

CAYLEY, A. S.; TINDALL A. P.; SAMPSON W. J.; BUTCHER A. R. Electropalatographic and cephalometric assessment of myofunction therapy in open bite subjects. Aust. Orthod. J., Brisbane, v. 16, n. 1, p. 23-33, mar. 2000.

\section{Conclusion}

The results of this study allowed to conclude that the cephalometric measures of the studied sample were not related to the patients' age and there was no difference between the groups regarding their components' age.

Based on the cephalometric analysis composed by the angles NS.GoGn, NSGn and Facial Axis and on the application of the mathematical formula obtained in this study, it is possible to reliably perform the differential diagnosis between dentoalveolar and skeletal open bite, for clinical and research purposes.

CIRELLI, C. C.; MARTINS, L. P.; MELO, A. C. M.; PAULIN, R. F. Mordida aberta anterior associada ao hábito de sucção de chupeta-relato de caso clínico. J. Bras. Fonoaudiol., Curitiba, v. 21, n. 6, p. 36-39, jan/mar. 2001.

DEGAN, V. V. Influência da associação da remoção de hábitos de sucção e terapia miofuncional nas alterações musculares, funcionais e oclusais. 2004. 204 f. Tese (Doutorado em Fisiologia Oral) - Faculdade de Odontologia de Piracicaba da Universidade de Campinas, Piracicaba.

DE FREITAS, M. R.; BELTRAO, R. T.; JANSON, G, HENRIQUES, J. F.; CANCADO, R. H. Long-term stability of anterior open bite extraction treatment in the permanent dentition. Am. J. Orthod. Dentofacial. Orthop., St. Louis, v. 125, n. 1, p. 78-87, jan. 2004.

FARIA, P. T.; RUELLAS, A. C. O.; MATSUMOTO, M. A N.; ANSELMO-LIMA, W. T.; PEREIRA, F. C. Dentofacial morphology of mouth breathing children. Braz. Dent. J., Ribeirão Preto, v. 13, n. 2, p. 129-132, nov. 2002.

FAYYAT, E. L. R. C. A influência de hábitos orais e respiração bucal no aparecimento de mordida aberta anterior em crianças com dentição decídua. Rev. Fono Atual, São Paulo, v. 1, n. 12, p. 36-40, jun. 2000. 
FELÍCIO, C. M. Problemas ortodônticos e o papel das (dis)funções orofaciais. In: FELÍCIO, C. M. Fonoaudiologia aplicada a casos odontológicos: motricidade oral e audiologia. 1. reimp. São Paulo: Pancast, 2001. cap. 6, p. 173-196.

FELÍCIO, C. M.; FERREIRA-JERONYMO, R. R.; FERRIOLLI, B. H. V. M.; FREITAS, R. L. R. G Análise da associação entre sucção, condições miofuncionais orais e fala. Pró-Fono Revista de Atualização Científica, Barueri (SP), v. 15, n. 1, p. 31-40, jan.-abr. 2003.

FERRUGINI, A. M.; VALLE, A. C. F; SOARES, C. F; SCHETTINO, C. S.; CROCE, L. S. S.; LEITE, I. C. G Crescimento e desenvolvimento craniofacial. J. Bras. Fonoaudiol., Curitiba, v. 3, n. 11, p. 135-139, abr/jun. 2002.

FUJIKI, T.; INOUE, M.; MIYAWAKI, S.; NAGASAKI, T.; TANIMOT O, K. TAKANO-YAMAMOT O, T. Relationship between maxillofacial morphology and deglutitive tongue movement in patients with anterior open bite. Am. J. Orthod. Dentofacial. Orthop., St. Louis, v.125, n. 2 , p. 160-167, feb. 2004.

HENRIQUES, J. F. C.; JANSON, G.; ALMEIDA, R. R.; DAINESI, E. A.; HAYASAKI, S. M. Mordida aberta anterior: a importância da abordagem multidisciplinar e considerações sobre etiologia, diagnóstico e tratamento. apresentação de um caso clínico. Rev. Dental Press Ortodon. Ortop. Facial, Maringá, v. 5, n. 3, p. 29-36. mai/jun. 2000.

JANSON, G; VALARELLI, F. P.; HENRIQUES, J. F; DE FREITAS, M. R.; CANCADO, R. H. Stability of anterior open bite nonextraction treatment in the permanent dentition. Am. J. Orthod. Dentofacial. Orthop., St. Louis, v. 124, n. 3, p. 265-276, sep. 2003.

KAWAMURA， M.; NOJIMA，K.; NISHII， Y.; YAMAGUCHI, H. A cineradiographic study of deglutitive tongue movement in patients with anterior open bite. Bull. Tokyo Dent. Coll., Tokyo, v. 44, n. 3, p. 133-139, aug. 2003.

KLOCKE, A.; NANDA, R. S.; KAHL-NIEKE, B. Anterior open bite in the deciduous dentition: longitudinal follow-up and craniofacial growth considerations. Am. J. Orthod. Dentofacial. Orthop., St. Louis, v. 122, n. 4, p. 353-358, oct. 2002

KROGMAN, W. M.; SASSOUNI, V. A syllabies in roentgenografic cephalometry. Philadelphia: Library of Congress, 1957.

LOPES, L. D. Enfoque ortopédico maxilar. In: GONZALEZ, N. Z. T.; LOPES, L. D. Fonoaudiologia e ortopedia maxilar na reabilitação orofacial: tratamento precoce e preventivo, terapia miofuncional. São Paulo: Santos, 2000. cap. 8, p. 98-99.

PACHECO, F.; MIRANDA, F. M.; RUELLAS, A. C. O. A importância do comportamento lingual no diagnóstico e tratamento precoces e na prevenção em ortodontia. $J$. Bras. Fonoaudiol., Curitiba, v. 1, n. 5, p. 23-27, out/dez. 2000.

PROFFIT, W. R. Contemporany orthodontics. 3. ed. St Louis: Mosby. Inc. 2000. 742 p.

PROFFIT, W. R.; FIELDS, H. W. Oclusal forces in normal and long face children. J. Dent. Res., Chicago, v. 52, n. 5, p. 571-574, may. 1983 .

PULITI, S. K. M. Revisão de métodos de análise craniofacial de interesse para o fonoaudiólogo. 2002. 153 f. Monografia (Especialização em Motricidade Oral) - Curso de Fonoaudiologia da Universidade de Ribeirão Preto, Ribeirão Preto.

SANTOS, L. K.; ÁVILA, C. R. B.; CECHELA, C.; MORAIS, Z. R. Ocorrência de alterações de fala, do sistema sensorimotor oral e de hábitos orais em crianças préescolares e escolares da $1^{\circ}$ série do $1^{\circ}$ grau. Pró-Fono Revista de Atualização Científica, Carapicuiba, v. 12, n. 2,p.93-101, set. 2000.

STEINER, C. C. Cephalometrics for you and me. Am. J. Orthod., St. Louis, v. 10, n. 39, p. 729-755, oct. 1953.

STUANI, A. S.; MATSUMOTO, M. A.; STUANI, M. B. Cephalometric evaluation of patients with anterior openbite. Braz. Dent. J., Ribeirão Preto, v. 11, n. 1, p. 35-40. jul. 2000.

YAMAGUCHI, H.; SUEISHI, K. Malocclusion associated with abnormal posture. Bull. Tokyo Dent. Coll., Tokyo, v. 44, n. 2, p. 43-54, may. 2003. 